\title{
Treatment of Experimental Septic Shock with Microencapsulated Antisense Oligomers to NF- $\kappa \mathrm{B}$
}

\author{
MARTIN J. D'SOUZA, ZHAOWEI JIN, and CARL W. OETTINGER
}

\begin{abstract}
NF- $\mathrm{B}$ B is an ideal target for inhibition of proinflammatory cytokines. The purpose of this study was to determine if microencapsulated antisense oligomer to NF- $\kappa \mathrm{B}$ can inhibit proinflammatory cytokine release in response to Esherichia coli endotoxin and bacteria. Microencapsulation takes advantage of the phagocytic function of the macrophage to deliver the oligomer intracellularly and enhance the effect. Albumin microcapsules $1 \mu \mathrm{m}$ in size were prepared by a nebulization method containing antisense oligomers to NF- $\kappa$ B. $E$. coli endotoxin was incubated in $1 \mathrm{ml}$ aliquots of whole blood. Microencapsulated antisense to NF- $\kappa \mathrm{B}$ was given, and the inhibition of tumor necrosis factor (TNF), interleukin-1 (IL-1), IL-6, and IL-8 was compared with similar amounts of oligomer in solution. Endotoxic shock was produced in rats using $E$. coli endotoxin $(15 \mathrm{mg} / \mathrm{kg})$. Peritonitis was induced by injecting $10^{10} \mathrm{CFU}$ E. coli. Cytokines were measured after simultaneous and delayed $(4 \mathrm{~h})$ administration of antisense to NF- $\kappa \mathrm{B}$ in microcapsules and solution form. TNF was suppressed by $81 \%$ in whole blood, $56 \%$ in the endotoxic shock model, $89 \%$ in the peritonitis model (simultaneous treatment), and $56 \%$ in the delayed treatment group. Survival was $70 \%$ in the endotoxic shock group, $80 \%$ in the simultaneous peritonitis group, and $70 \%$ in the delayed treatment group. Microcapsule treatment using antisense to NF- $\kappa$ B suppressed TNF and IL-1 levels and mortality significantly better than all solution treatment groups in the whole blood model, endotoxic shock model, and peritonitis model.
\end{abstract}

\section{INTRODUCTION}

$\mathbf{N}^{\mathrm{r}}$ F-KB, THE NUCLEAR TRANSCRIPTION FACTOR, plays an integral role in initiating the synthesis of tumor necrosis factor (TNF) and other proinflammatory cytokines. ${ }^{(1)} \mathrm{NF}-\kappa \mathrm{B}$ is activated by a wide variety of stimuli, including endotoxin and gram-negative bacteria. $\mathrm{NF}-\kappa \mathrm{B}$ has been shown to activate over 150 target genes, including 27 different cytokines and chemokines. $^{(2)} \mathrm{NF}-\kappa \mathrm{B}$, a tetramer, exists in an inactive form in the cytoplasm complexed to $\mathrm{I} \kappa \mathrm{B}$. A series of reactions involving phosphorylation of $\mathrm{I} \kappa \mathrm{B}$, ubiquitination, and subsequent degradation by the proteasome leads to separation of NF- $\kappa \mathrm{B}$, followed by immediate translocation to the nucleus. ${ }^{(3-7)}$ This series of reactions results in activation of transcription factors for various proinflammatory cytokines, such as TNF, interleukin-1 (IL-1), and other cytokines involved in the inflammatory response. Studies have documented the association of $\mathrm{NF}-\kappa \mathrm{B}$ activation in septic shock, inflammatory bowel disease, rheumatoid arthritis, glomerulonephritis, and many other inflammatory conditions. ${ }^{(8-19)}$ Inhibition of $\mathrm{NF}-\kappa \mathrm{B}$ may lead to an important therapeutic strategy to alter the inflammatory response in pathologic conditions characterized by proinflammatory cytokine activation, such as septic shock. ${ }^{(20-23)}$

Antisense compounds offer great potential to inhibit the synthesis of individual proteins, although intracellular penetration of antisense compounds has proven to be a limiting factor in their effectiveness. ${ }^{(24)}$ Antisense compounds must penetrate the cell to interact with the specific nuclear mRNA that causes in protein synthesis. We have recently demonstrated greatly improved effectiveness in cytokine inhibition by intracellular delivery of an antisense oligomer to TNF using albumin microcapsules in the models of endotoxin and septic shock in rats. ${ }^{(25)}$ Albumin microcapsules $1 \mu \mathrm{m}$ in size containing water-soluble drugs are readily phagocytized by macrophages and other phagocytic cells. Macrophages produce the majority of proinflammatory cytokines in response to stimuli, such as endotoxin. By taking advantage of the normal phagocytic function of the macrophage, drugs contained in microspheres are delivered intracellularly, producing a more localized, concentrated effect. 
We have developed three models to compare the effectiveness of microencapsulated drugs with that of drugs in solution. The whole blood model is an in vitro model consisting of all the normal cellular and enzymatic components of blood. We previously described the cytokine kinetics in this model after endotoxin stimulation. ${ }^{(26)}$ Incubation of drugs in solution can be compared with equivalent amounts of microencapsulated drugs in cytokine inhibition after endotoxin stimulation. In the endotoxic shock model, a lethal dose of endotoxin in rats is used to compare effectiveness of cytokine inhibition of compounds in solution and in microencapsulated form. If these models demonstrate significant TNF and IL-1 inhibition and improve survival, the compound is tested in a peritonitis model, which is a model of compartmentalized infection with potential clinical relevance.

Previous studies in our laboratory have documented enhanced suppression of TNF and IL-1 and survival in these models using microencapsulated drugs, such as neutralizing antibodies to TNF and IL-1, clodronate, CNI-1493 (a guanyl hydrazone compound that inhibits mitogen-activated protein [MAP] p38 kinase activity), and antisense oligomers to TNF, compared with equivalent amounts of drug in solution. ${ }^{25,27-30)}$

It is the purpose of this investigation to determine if microencapsulated antisense oligomers to NF- $\kappa \mathrm{B}$ inhibit proinflammatory cytokine production both in vitro and in vivo and improve survival using in vivo models.

\section{MATERIALS AND METHODS}

The methods used in this study are similar to those used in previously reported investigations from our laboratory comparing the effectiveness of microencapsulated neutralizing antibodies to TNF and IL-1, CNI-1493, clodronate, and antisense oligomers to TNF with equivalent doses of the drug in solution. ${ }^{(25,27-31)}$

\section{Animals}

Fischer rats weighing 100-150 g were housed in a controlled environment with a 12-h light/dark cycle and free access to food and water. This study was approved by the Institutional Review Board for the care of animals at Mercer University. The animals were cared for according to the guidelines of the National Institutes of Health.

\section{Escherichia coli culture}

Gram-negative E. coli (serotype 086:K61) was obtained from ATCC (Rockville, MD) and grown until midlog phase in a trypticase-soy broth medium by incubation at $37^{\circ} \mathrm{C}$ in an atmosphere containing $5 \% \mathrm{CO}_{2}$. E. coli was concentrated by centrifugation, and the volume was adjusted to give an optical density (OD) of $650 \mathrm{~nm}$ spectrophotometrically so that each milliliter contained approximately $10^{10}$ colony-forming units (CFU) of E. coli. E. coli was tested for sensitivity to gentamicin.

\section{$N F-\kappa B$ and TNF antisense oligomers}

$\mathrm{NF}-\kappa \mathrm{B}$ antisense was targeted to the p65 subunit of the nuclear factor with the sequence 5'GGA AAC AGA TCG TTC
ATG-3'. TNF antisense was 5'-CAT GCT TTC TGT GCT CAT GGT GTC-3'. These antisense compounds are morpholino oligomers, kindly provided by AVI Biopharma (Corvallis, OR). A nonspecific scrambled oligomer was also provided as a control.

\section{Microsphere preparation}

Microspheres were prepared by an emulsion method using a biodegradable rodent albumin matrix (U.S. patent 6,555,110 B1). The microspheres were prepared by dissolving the NF- $\kappa \mathrm{B}$ oligomers and albumin (1:2) or only albumin (for blanks) in phosphate-buffered saline (PBS) and emulsifying with olive oil (maintained at $10-15^{\circ} \mathrm{C}$ ) containing $0.1 \%$ span 85 (Sigma Chemical Company, St. Louis, MO). Dispersion of the solution containing albumin and NF- $\kappa$ B oligomers in olive oil resulted in the formation of microspheres. After $10 \mathrm{~min}$ of emulsification, the albumin was cross-linked using glutaraldehyde. The emulsion was stirred with a magnetic stirrer at $5000 \mathrm{rpm}$ for 30 min to separate the microspheres. The microspheres were washed with hexane to remove the olive oil and sized with sequential reduction with sequential membrane filters that were $>0.75 \mathrm{um}$ in size. The microspheres were freeze-dried for $5 \mathrm{~h}$ and stored at $-70^{\circ} \mathrm{C}$. The concentration of drug in each milligram of microsphere was $0.33 \mathrm{mg}$, or $33.33 \%$ by weight.

\section{Whole blood model}

The whole blood model was used to compare the effectiveness of microencapsulation of antisense to NF- $\kappa \mathrm{B}$ in inhibition of TNF, IL-1, IL-6, and IL-8 with equivalent concentrations of the drug in solution in vitro. This method has been described in detail. ${ }^{(26)}$ Whole blood $(35 \mathrm{ml})$ was drawn from 6 normal human volunteers who were healthy and taking no medications. The blood was separated into aliquots and placed into 1-ml wells. E. coli endotoxin $(10 \mu \mathrm{g})$ was added to each sample, and samples were incubated. Samples were analyzed by ELISA after $4 \mathrm{~h}$ incubation for TNF, $6 \mathrm{~h}$ for IL-6, and $24 \mathrm{~h}$ for IL- 1 and IL-8. ${ }^{(32,33)}$ The following groups were studied:

1. Control: E. coli endotoxin, $10 \mu \mathrm{g} / \mathrm{ml}+$ saline

2. NF- $\kappa$ B antisense in solution, 200 and $300 \mu \mathrm{g} / \mathrm{ml}$ added $1 \mathrm{~h}$ prior to addition of E. coli endotoxin, $10 \mu \mathrm{g} / \mathrm{ml}$

3. NF- $\kappa$ B non-sense (scrambled) oligomer, 200 and $300 \mu \mathrm{g}$

4. Microencapsulated antisense oligomers to NF- $\kappa \mathrm{B}, 200$ and $300 \mu \mathrm{g} / \mathrm{ml}$

5. Microencapsulated non-sense (scrambled) oligomers, 200 and $300 \mu \mathrm{g} / \mathrm{ml}$

6. Microencapsulated oligomers to TNF and NF- $\kappa \mathrm{B}$ were compared in a dose of $300 \mu \mathrm{g}$ to determine their relative potency in TNF, IL-1, IL-6, and IL-8 inhibition

\section{Macrophage viability}

Macrophages were incubated with microcapsules containing antisense to NF- $\kappa$ B for $96 \mathrm{~h}$ to determine if the antisense caused the cells to die. Cell viability was evaluated by the addition of crystal violet dye at a concentration of $0.2 \%$. After a 10 -min incubation period, the excess dye was washed from the wells containing the cells, and the cells were observed microscopically. Nonviable cells take up crystal violet and do not stain 
blue but remain translucent. In each well, four different fields were examined, and a total of 100 cells were counted. After $72 \mathrm{~h}$ of incubation, $96 \%$ of the cells were determined to be viable. All comparisons were made relative to control groups where no microencapsulated drug was added.
Endotoxic shock model

Endotoxic shock was produced in rats weighing approximately $150 \mathrm{~g}$ by intravenous (i.v.) injection of $15 \mathrm{mg} / \mathrm{kg} \mathrm{E}$. Coli endotoxin. TNF and IL-1 were measured by ELISA at 0 h, 4 h,
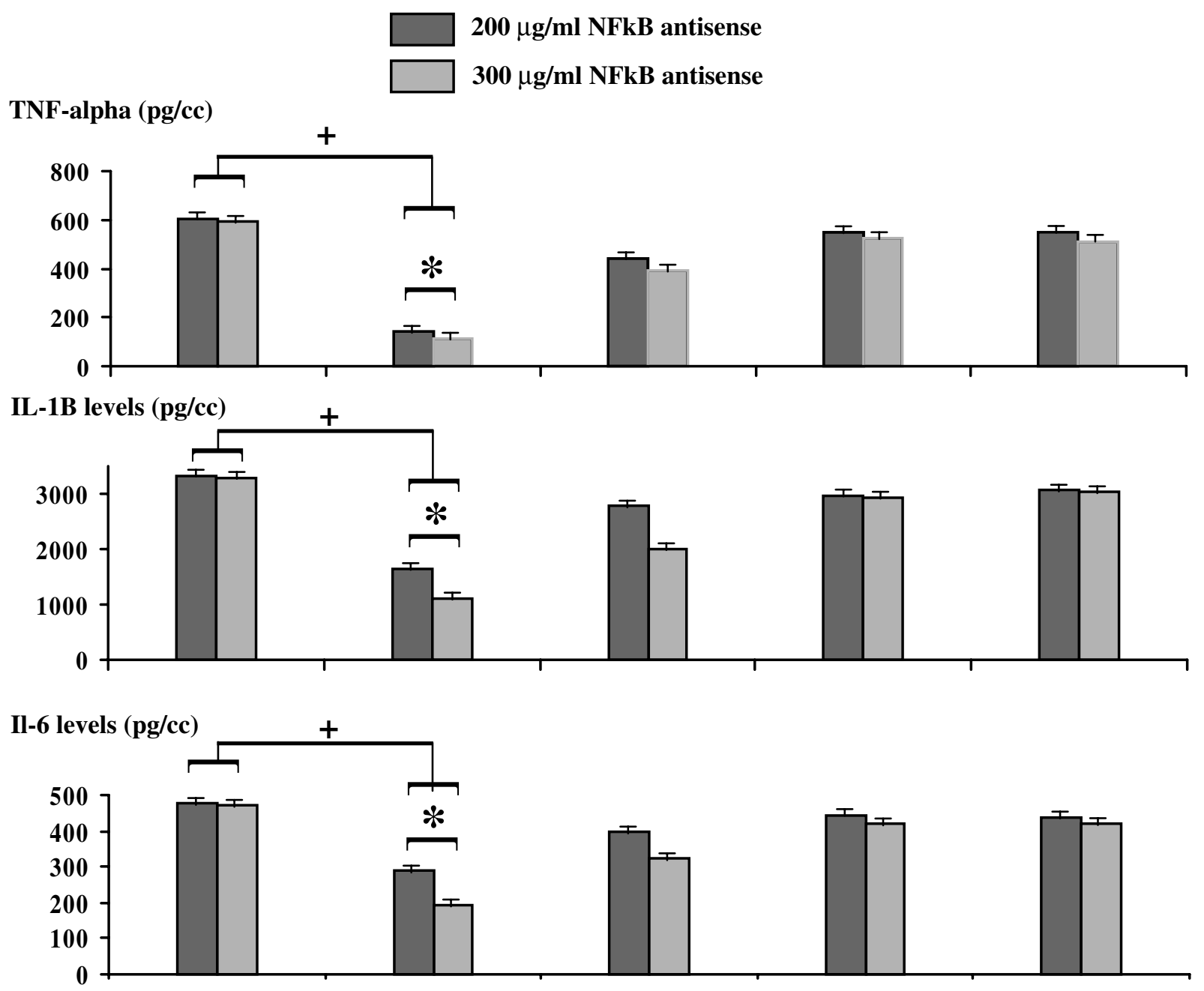

\section{IL-8 levels (pg/cc)}

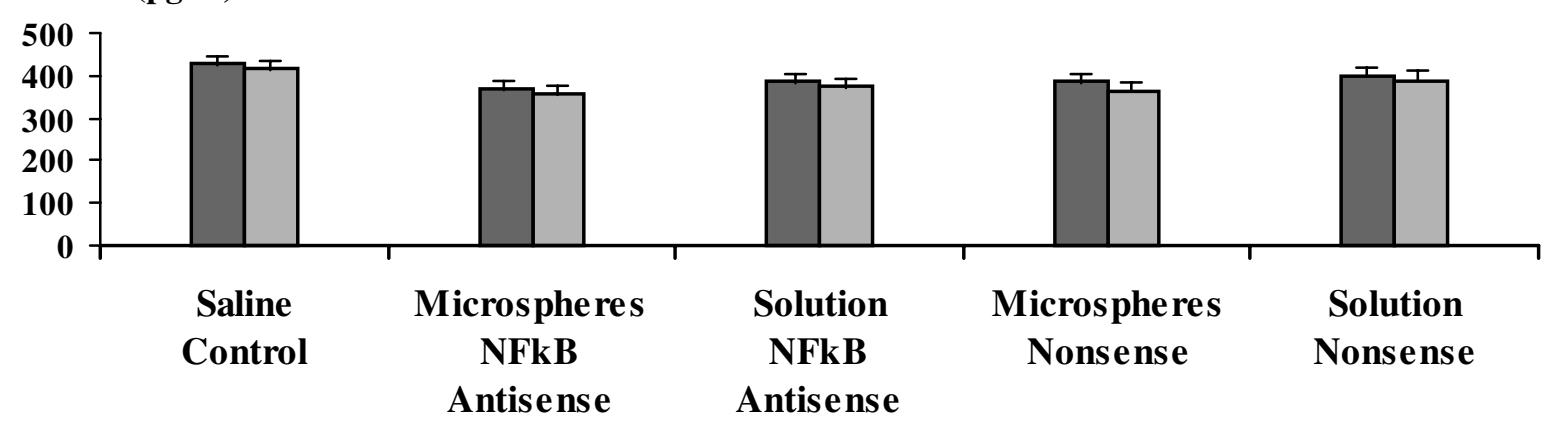

FIG. 1. Whole blood was incubated with $E$. coli endotoxin $(10 \mu \mathrm{g} / \mathrm{ml})$. The levels of TNF, IL-1, IL-6, and IL-8 were compared, from left to right: control, after the addition of microspheres containing antisense $200 \mu \mathrm{g}$ and $300 \mu \mathrm{g}$, antisense to NF$\kappa \mathrm{B}$ in solution 200 and $300 \mu \mathrm{g}$, scrambled antisense 200 and $300 \mu \mathrm{g}$, and scrambled antisense in solution ( 200 and $300 \mu \mathrm{g}$ ). SEM is noted above each bar. TNF was measured after $4 \mathrm{~h}$ incubation, IL-1 after $24 \mathrm{~h}$ incubation, IL-6 after $6 \mathrm{~h}$ incubation, and IL-8 after $24 \mathrm{~h}$ incubation. ${ }^{*} p<0.05$ comparing $300 \mu \mathrm{g}$ with $200 \mu \mathrm{g}$ antisense to $\mathrm{NF}-\kappa \mathrm{B} ;{ }^{+} p<0.05$, saline control vs. corresponding microsphere cytokine level. 
$8 \mathrm{~h}$, and $24 \mathrm{~h}$. The animals were observed for 5 days (120 h). Microencapsulated NF- $\kappa \mathrm{B}$ was given i.v. $(n=6)$ in doses of $50 \mu \mathrm{g}, 100 \mu \mathrm{g}, 150 \mu \mathrm{g}, 200 \mu \mathrm{g}$, and $300 \mu \mathrm{g}$ to determine the relative effect on TNF inhibition. After determining the results of the dose response, a dose of $300 \mu \mathrm{g}$ was given $(n=10)$ and the parameters were determined.

\section{Peritonitis model}

Peritonitis was induced in 10 rats weighing approximately $150 \mathrm{~g}$ by intraperitoneal (i.p.) injection of $10^{10}$ organisms of $E$. coli. Gentamicin $(15 \mathrm{mg} / \mathrm{kg})$ was given i.p. for 3 consecutive days to all groups. The animals were observed for 5 days

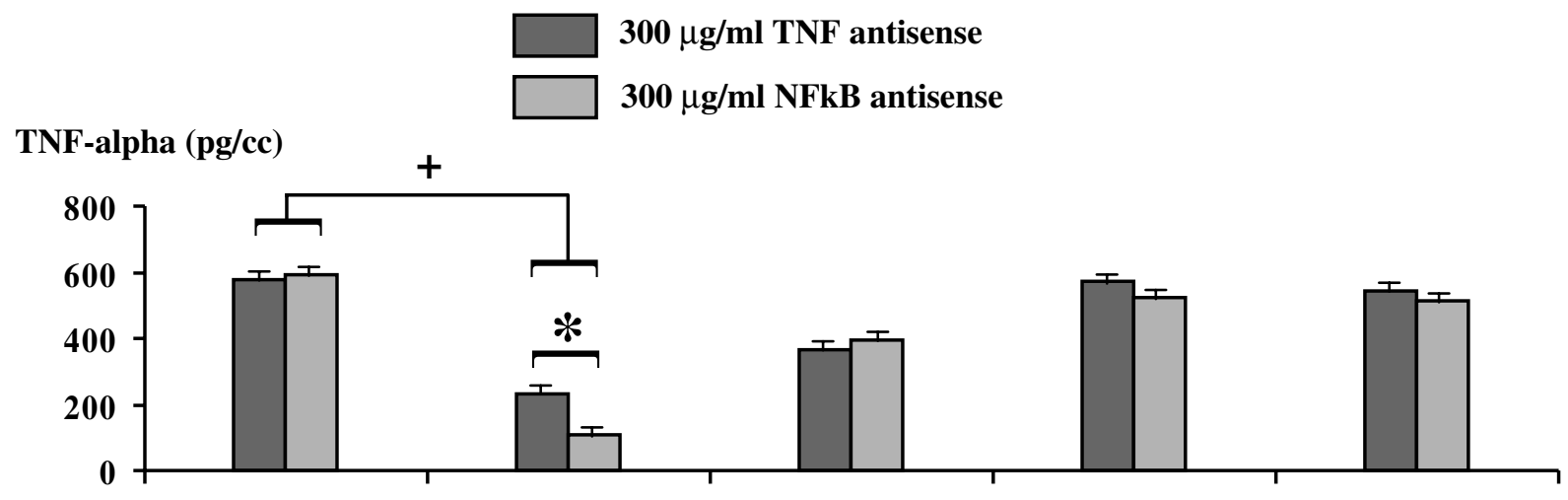

IL-1B levels (pg/cc)

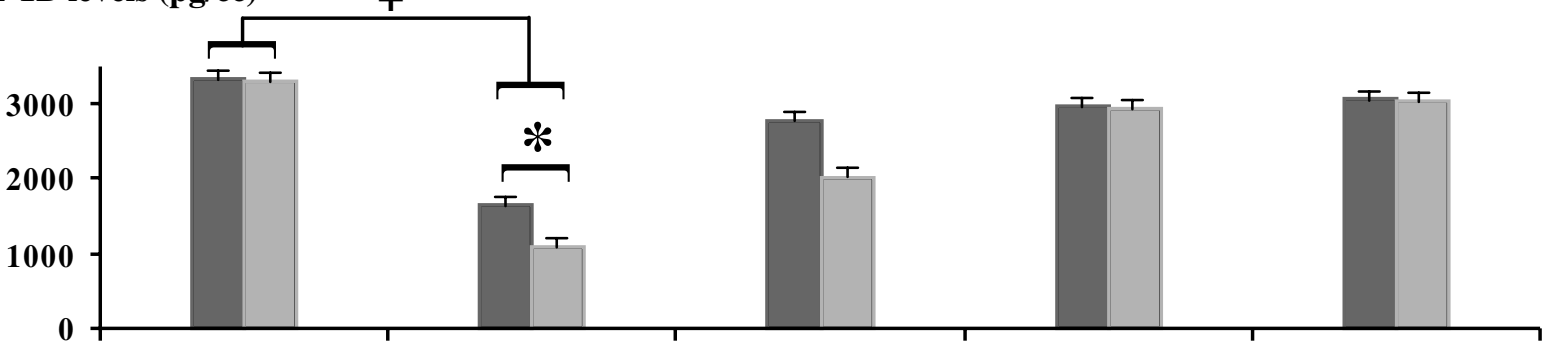

Il-6 levels (pg/cc)

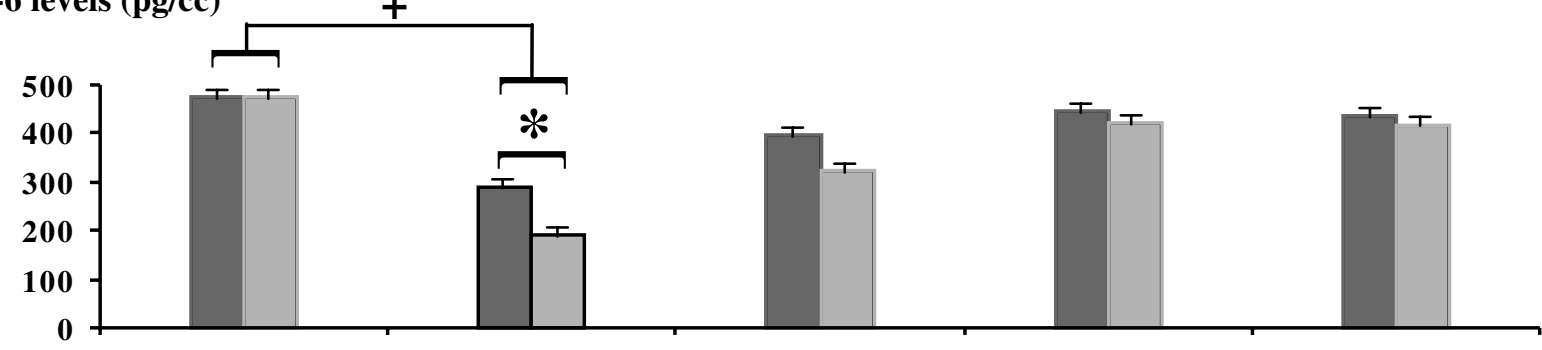

IL-8 levels (pg/cc)

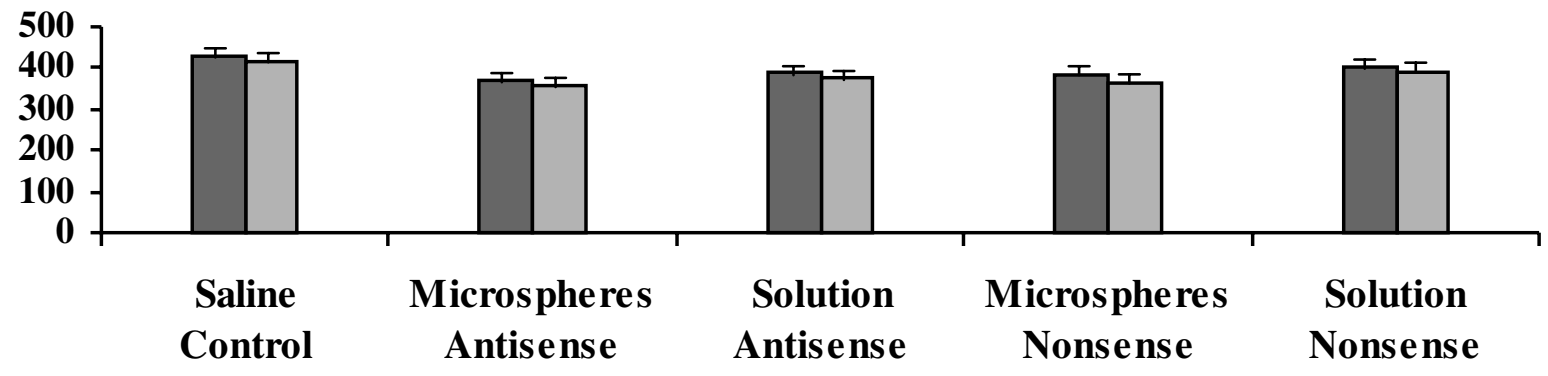

FIG. 2. Whole blood was incubated with $E$. coli endotoxin $(10 \mu \mathrm{g} / \mathrm{ml})$. The levels of TNF, IL-1, IL-6, and IL- 8 were compared after the addition of antisense or scrambled oligomer to TNF or NF- $\kappa$ B either in microsphere or solution form ( $300 \mu \mathrm{g} / \mathrm{ml}) \mathrm{as}$ in Figure 1. The relative capacity for cytokine inhibition of antisense to TNF and NF- $\kappa \mathrm{B}$ was evaluated. SEM is noted above the bar. ${ }^{+} p<0.05$, saline control vs corresponding cytokine level; ${ }^{*} p<0.05$, NF- $\kappa \mathrm{B}$ antisense $300 \mu \mathrm{g}$ vs. TNF antisense $300 \mu \mathrm{g}$. 
(120 h). TNF and IL-1 were measured by ELISA in all groups at 0 (control), 4, 8, and $24 \mathrm{~h}$. Survival was evaluated.

\section{Simultaneous treatment}

E. coli i.p. injection and the following treatments were given simultaneously and then daily for an additional 2 days: (1) control $(n=10),(2)$ solution antisense to NF- $\kappa \mathrm{B}$ i.v. $(200 \mu \mathrm{g}$ and $400 \mu \mathrm{g} / \mathrm{rat} ; 400 \mu \mathrm{g}$ antisense was given to produce a maximal effect $(n=10)$, and (3) microencapsulated antisense to NF- $\kappa \mathrm{B}$ i.v. $200 \mu \mathrm{g}$ and $400 \mu \mathrm{g} / \mathrm{rat}(n=10)$.

\section{Delayed treatment}

Treatment with $200 \mu \mathrm{g}$ and $400 \mu \mathrm{g}$ oligomer was given to 10 rats $4 \mathrm{~h}$ after the dose of i.p. E. coli, as in the simultaneous treatment group. At this time, the peak TNF level after the induction of peritonitis had occurred. This experiment was performed to evaluate the effectiveness of treatment after the infection was established and TNF had reached its peak. This would be comparable to treating a patient after an infection had begun. An additional two doses of oligomer were given i.v. at 24 and $48 \mathrm{~h}$.

\section{Statistical analysis}

ANOVA was used to determine statistical significance at $p<$ 0.05 . Student's $t$-test and Kaplan-Meier survival curves were used where appropriate.

\section{RESULTS}

\section{Whole blood model}

The effect of microencapsulated antisense oligomer to NF- $\kappa \mathrm{B}$ on suppression of TNF, IL-1, IL-6, and IL-8 are depicted in Figure 1. TNF was suppressed $81 \%$ by $300 \mu \mathrm{g} / \mathrm{ml} \mathrm{mi-}$ croencapsulated antisense oligomer to NF- $\kappa$ B and $76 \%$ by 200 $\mu \mathrm{g} / \mathrm{ml}$. The equivalent solution doses reduced TNF by $34 \%$ and $27 \%$, respectively ( $p<0.05$ for microsphere reduction vs. solution). Microspheres containing scrambled (non-sense) antisense produced no effect in either microencapsulated or solution form. A similar pattern but a lesser amount of inhibition was seen with IL-1 (microencapsulated antisense 53.3\%, solution $22 \%, p<0.05$ ) and IL-6 (microcapsules $45.5 \%$, solution $25.9 \%, p<0.05)$. The IL-8 level was not affected by the microencapsulated antisense or solution antisense. Comparison of TNF inhibition of $300 \mu \mathrm{g}$ microencapsulated antisense to NF- $\kappa \mathrm{B}$ and TNF is shown in Figure 2. TNF was inhibited by $81 \%$ with NF- $\kappa$ B antisense and $59 \%$ using TNF antisense $(p<$ $0.05)$. Significantly improved inhibition of IL-1 and IL-6 was also observed with antisense to NF- $\kappa \mathrm{B}$ compared with antisense to TNF.

\section{Endotoxic shock model}

The dose titration of TNF concentrations and survival to rats given $15 \mathrm{mg} / \mathrm{kg}$ endotoxin is shown in Table 1 and Figure 3. Progressive increases in microencapsulated antisense to NF- $\kappa \mathrm{B}$ $(50 \mu \mathrm{g}, 100 \mu \mathrm{g}, 150 \mu \mathrm{g}, 200 \mu \mathrm{g}$, and $300 \mu \mathrm{g}$ per rat; $n=6$ in each group) caused a progressive decline in TNF concentration and increased survival in the rats. Table 2 shows the TNF response and survival in the endotoxic shock model to antisense to NF-kB, $300 \mu \mathrm{g}$ antisense in solution and microencapsulated scrambled antisense $(n=10)$ in each group. The only significant improvement in both survival and TNF inhibition occurred in the groups given microencapsulated antisense to NF- $\kappa$ B. Antisense to NF- $\kappa \mathrm{B}(300 \mu \mathrm{g})$ produced a $58 \%$ inhibition of TNF at $4 \mathrm{~h}$ compared with control values and a survival of $70 \%$ after $120 \mathrm{~h}$ observation. The microcapsules containing scrambled antisense produced no effect and were not further evaluated.

\section{Peritonitis model}

The results for TNF, IL-1, and survival of the simultaneous treatment groups are depicted in Table 3 and Figure 3. In the

Table 1. Endotoxin Dose-Response ${ }^{\mathrm{a}}$

\begin{tabular}{|c|c|c|c|c|c|c|}
\hline \multirow{2}{*}{$\begin{array}{l}M S N F-k B \\
\text { antisense } \\
\mu g / r a t\end{array}$} & \multicolumn{6}{|c|}{$T N F-\alpha, p g / m l$} \\
\hline & $O \mathrm{~h}$ & $4 h$ & $8 h$ & $24 h$ & $48 h$ & $120 \mathrm{~h}$ \\
\hline Control (0) & $40 \pm 4$ & $3728 \pm 127$ & $2102 \pm 129$ & $1264 \pm 87$ & - & - \\
\hline 50 & $34 \pm 3$ & $3059 \pm 69$ & $2015 \pm 46$ & $1039 \pm 68$ & $443 \pm 43$ & - \\
\hline 100 & $36 \pm 2$ & $2863 \pm 60$ & $1808 \pm 71$ & $966 \pm 42$ & $404 \pm 8$ & - \\
\hline 150 & $35 \pm 3$ & $2319 \pm 32$ & $1547 \pm 30$ & $855 \pm 34$ & $340 \pm 17$ & - \\
\hline 200 & $34 \pm 4$ & $1893 \pm 39$ & $1037 \pm 57$ & $575 \pm 31$ & $309 \pm 24$ & - \\
\hline \multirow[t]{2}{*}{300} & $33 \pm 3$ & $1628 \pm 26$ & $827 \pm 32$ & $309 \pm 10$ & $207 \pm 7$ & - \\
\hline & \multicolumn{6}{|c|}{ Survival (no. of rats) } \\
\hline Control & 6 & 6 & 6 & 2 & 0 & 0 \\
\hline 50 & 6 & 6 & 6 & 6 & 4 & 1 \\
\hline 150 & 6 & 6 & 6 & 6 & 6 & 2 \\
\hline 200 & 6 & 6 & 6 & 6 & 6 & 3 \\
\hline 300 & 6 & 6 & 6 & 6 & 6 & 4 \\
\hline
\end{tabular}

${ }^{a}$ Endotoxic shock was produced in rats by giving $15 \mathrm{mg} / \mathrm{kg}$ i.v. E. coli endotoxin simultaneously with $50 \mu \mathrm{g}, 100 \mu \mathrm{g}, 150 \mu \mathrm{g}$, $200 \mu \mathrm{g}$, and $300 \mu \mathrm{g}$ microencapsulated antisense (MS) to NF- $\kappa \mathrm{B}$, followed by measurement of TNF at $4,8,24$, and $48 \mathrm{~h}( \pm$ SEM). 


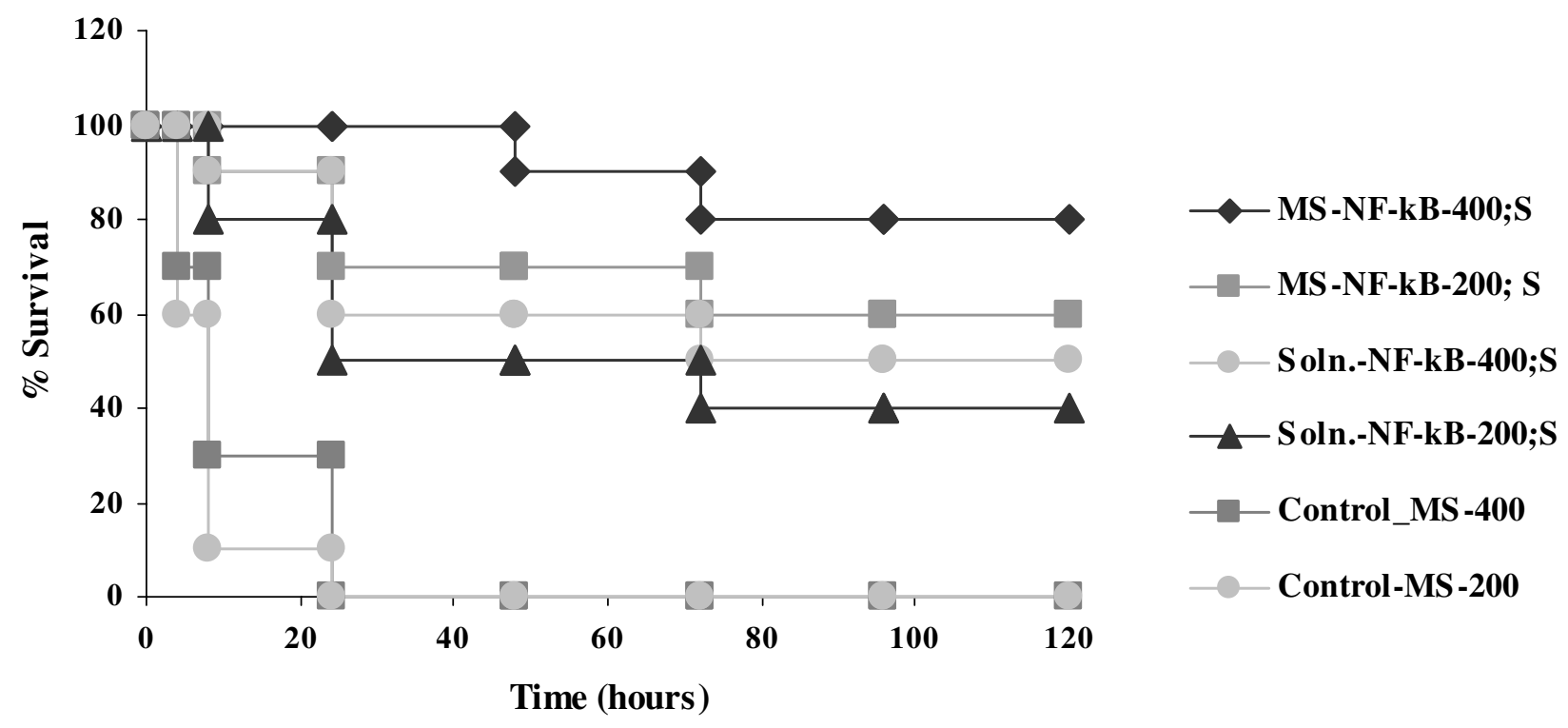

FIG. 3. Kaplan-Meier survival curve comparing survival of rats $(n=10$ in each group) after induction of peritonitis with i.p. E. coli. All groups were given gentamicin. The control group contained blank microspheres (MS). Antisense to NF- $\kappa$ B (200 and $400 \mu \mathrm{g}$ ) was given simultaneously with the induction of peritonitis in both solution and microencapsulated (MS) forms. $p=$ $<0.05$ in comparing each solution group with the corresponding dose of microencapsulated antisense to NF- $\kappa \mathrm{B}$.

group in which $200 \mu \mathrm{g}$ antisense to NF- $\kappa \mathrm{B}$ was given simultaneously with the induction of peritonitis, TNF concentration was suppressed by $80 \%$ at $4 \mathrm{~h}$ compared with $58 \%$ suppression by an equivalent amount of antisense oligomer to NF- $\kappa \mathrm{B}$ given in solution $(p<0.05)$. In the group given $400 \mu \mathrm{g}$ microencapsulated antisense to NF- $\kappa \mathrm{B}$, TNF was suppressed by $84 \%$ compared with $69 \% \mu$ sing antisense to NF- $\kappa \mathrm{B}$ in solution $(p<0.05)$. IL-1 concentration measured at $24 \mathrm{~h}$ was suppressed $40 \%$ by $200 \mu \mathrm{g}$ microencapsulated oligomer to NF$\kappa \mathrm{B}$ compared with $3.4 \%$ by solution treatment $(p<0.05)$. IL-I concentration was suppressed by $58 \%$ in the microencapsu- lated group given $400 \mu \mathrm{g}$ compared with $11 \%$ in the solution group $(p<0.05)$. Survival in the microsphere group given 400 $\mu \mathrm{g}$ was $80 \%$ compared with $50 \%$ in the solution group $(p<$ 0.05 ). Survival in the group given $200 \mu \mathrm{g}$ microencapsulated antisense to NF- $\kappa \mathrm{B}$ was $60 \%$ compared with $40 \%$ in the solution group $(p<0.05)$.

The results for TNF, IL-1, and survival of the delayed treatment group (antisense in solution or microencapsulated form given $4 \mathrm{~h}$ after inoculation of bacteria) are depicted in Table 4 and Figure 4 . TNF levels measured $8 \mathrm{~h}$ after inoculation of bacteria (4 after administration of antisense) de-

Table 2. Endotoxin, MS Treatment ${ }^{\mathrm{a}}$

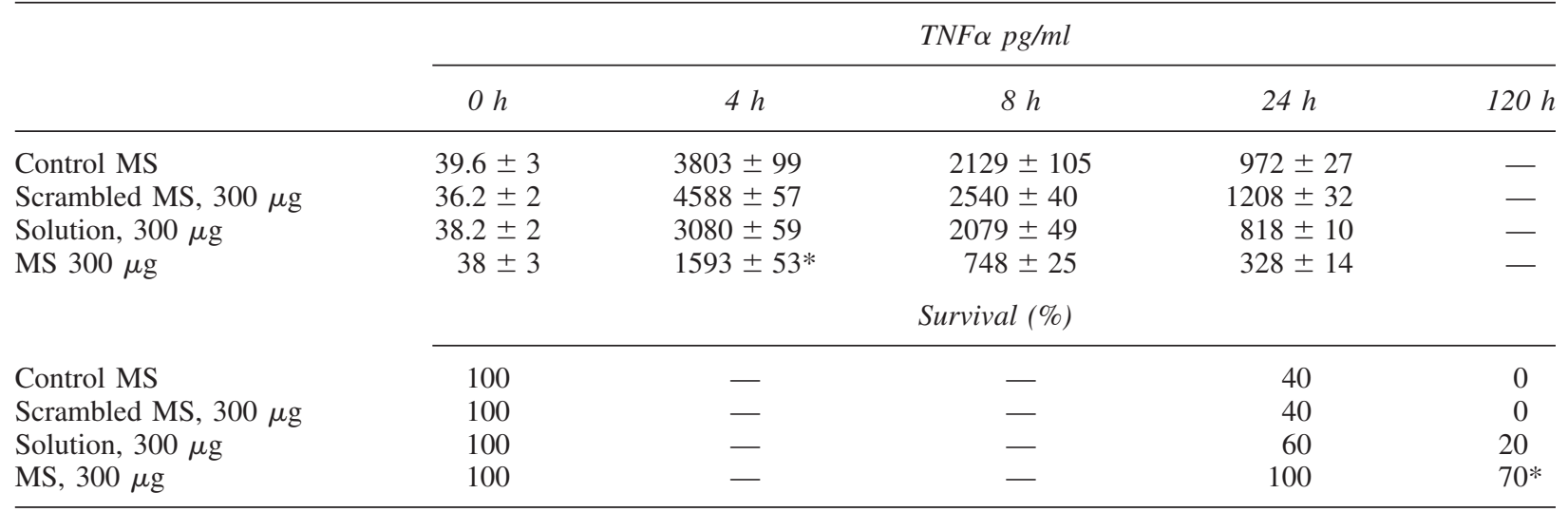

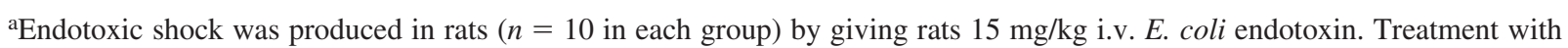
$300 \mu \mathrm{g}$ antisense oligomers to NF- $\kappa \mathrm{B}$ was given in solution form, microencapsulated (MS) form, and scrambled oligomers, with measurement of TNF \pm SEM for $48 \mathrm{~h}$.

$*_{p}<0.05$ microencapsulated antisense to NF- $\kappa \mathrm{B}$ compared with solution antisense. 
Table 3. Peritonitis, Simultaneous Treatment ${ }^{\mathrm{a}}$

\begin{tabular}{lccrc}
\hline & $0 h$ & $4 h$ & $8 h$ & $24 h$ \\
\hline TNF- $\alpha, \mathrm{pg} / \mathrm{ml}$ & & & & \\
Control & $30 \pm 2$ & $5015 \pm 56$ & $3025 \pm 66$ & $2767 \pm 39$ \\
$200 \mu \mathrm{g}$ solution & 29 & $2068 \pm 25$ & $1845 \pm 19$ & $1118 \pm 49$ \\
$200 \mu \mathrm{g}$ MS & 32 & $1550 \pm 13 \pm 26^{*}$ & $1326 \pm 18$ & $545 \pm 11$ \\
$400 \mu \mathrm{g}$ solution & $39 \pm 2$ & $825 \pm 14 *$ & $669 \pm 16$ & $359 \pm 16$ \\
$400 \mu \mathrm{g}$ MS & $33 \pm 2$ & $315 \pm 12$ & $455 \pm 11$ & $498 \pm 6$ \\
IL-1, pg/ml & $36 \pm 2$ & $216 \pm 7$ & $305 \pm 7$ & $481 \pm 7$ \\
Control & $34 \pm 3$ & $113 \pm 5$ & $206 \pm 5$ & $300 \pm 12^{*}$ \\
$200 \mu \mathrm{g}$ solution & $37 \pm 3$ & $154 \pm 8$ & $254 \pm 7$ & $441 \pm 10$ \\
$200 \mu \mathrm{g}$ MS & $34 \pm 2$ & $103 \pm 3$ & $143 \pm 6$ & $207 \pm 6 *$ \\
$400 \mu \mathrm{g}$ solution & $34 \pm 2$ & & & \\
$400 \mu \mathrm{g}$ MS & & & & \\
\hline
\end{tabular}

aPeritonitis was induced in 10 rats in each group by i.p. injection of $10^{10} \mathrm{CFU}$ E. coli. Simultaneous treatment using antisense oligomers to NF- $\kappa \mathrm{B}$ in solution (200 $\mu \mathrm{g}$ and $400 \mu \mathrm{g}$ ) was compared with equivalent doses of microencapsulated antisense (MS) to NF- $\kappa$ B. TNF and IL-1 were measured by ELISA ( \pm SEM). Gentamicin was given to all groups.

$*_{p}<0.05$, comparing microencapsulated value with corresponding solution value of TNF or IL- 1 .

clined $18 \%$ in the group treated with $200 \mu \mathrm{g}$ microencapsulated antisense in contrast to no reduction in the group treated with solution $(p<0.05)$. TNF concentration declined by $35 \%$ in the group given $400 \mu \mathrm{g}$ microencapsulated oligomer compared with $26 \%$ in the group given oligomer in solution ( $p<0.05$ ). IL-1 concentration measured at $24 \mathrm{~h}$ decreased by $19 \%$ in the group given $200 \mu \mathrm{g}$ microencapsulated oligomer compared with $8 \%$ in the solution group $(p<$ 0.05). In the group given $400 \mu \mathrm{g}$ microencapsulated oligomer, IL-I reduction was $32 \%$ compared with $21 \%$ in the solution group. Survival in the microencapsulated group given $400 \mu \mathrm{g}$ oligomer was $70 \%$ compared with $30 \%$ in the solution group $(p<0.05)$. Survival in the group given 200 $\mu \mathrm{g}$ microencapsulated oligomer was $50 \%$ compared with $20 \%$ in the solution group $(p<0.05)$.

\section{DISCUSSION}

The results of this study document the effectiveness of microencapsulated antisense oligomers to NF- $\kappa$ B in inhibition of TNF using both in vitro and in vivo models of sepsis. Microencapsulated antisense oliogmers produced TNF $>$ IL-1 $>$ IL-6 inhibition to a significantly greater degree than comparable amounts of oligomer in solution using the whole blood model, which evaluates cytokine release after endotoxin stimulation in vitro. Interestingly, IL-8 was not suppressed by antisense to NF- $\kappa$ B. This may indicate alternative pathways for stimulation other than NF- $\kappa$ B. A similar lack of inhibition of IL-8 was seen in primates given microencapsulated antisense to NF- $\kappa$ B (unpublished observations). Superior TNF and IL-1 inhibition and survival were observed using the in vivo models

Table 4. Peritonitis, Delayed Treatment ${ }^{\mathrm{a}}$

\begin{tabular}{|c|c|c|c|c|}
\hline & $O h$ & $4 h$ & $8 h$ & $24 h$ \\
\hline \multicolumn{5}{|l|}{$\mathrm{TNF}-\alpha, \mathrm{pg} / \mathrm{ml}$} \\
\hline Control & $30 \pm 2$ & $5015 \pm 56$ & $3025 \pm 66$ & $2767 \pm 39$ \\
\hline $200 \mu \mathrm{g}$ solution & $34 \pm 1$ & $4530 \pm 59$ & $3775 \pm 46$ & $2243 \pm 37$ \\
\hline $200 \mu \mathrm{g}$ MS & $37 \pm 2$ & $3855 \pm 33^{*}$ & $2469 \pm 41$ & $1274 \pm 23$ \\
\hline $400 \mu \mathrm{g}$ solution & $32 \pm 2$ & $3505 \pm 61$ & $2249 \pm 24$ & $1524 \pm 52$ \\
\hline $400 \mu \mathrm{g} \mathrm{MS}$ & $31 \pm 2$ & $3015 \pm 32 *$ & $1945 \pm 41$ & $1044.3 \pm 25$ \\
\hline \multicolumn{5}{|l|}{$\mathrm{IL}-1, \mathrm{pg} / \mathrm{ml}$} \\
\hline Control & $36 \pm 2$ & $316 \pm 12$ & $455 \pm 11$ & $498 \pm 6$ \\
\hline $200 \mu \mathrm{g}$ solution & $35 \pm 2$ & $257 \pm 9$ & $344 \pm 11$ & $458 \pm 10$ \\
\hline $200 \mu \mathrm{g}$ MS & $34 \pm 3$ & $208 \pm 8$ & $250 \pm 9$ & $405 \pm 4 *$ \\
\hline $400 \mu \mathrm{g}$ solution & $34 \pm 3$ & $207 \pm 2$ & $305 \pm 5$ & $395 \pm 11$ \\
\hline $400 \mu \mathrm{g}$ MS & $36 \pm 2$ & $171 \pm 8$ & $202 \pm 9$ & $340 \pm 12 *$ \\
\hline
\end{tabular}

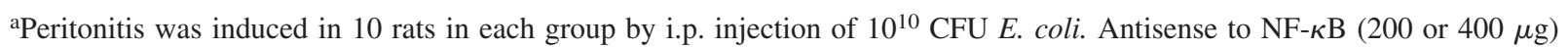
was given in microencapsulated (MS) or solution form $4 \mathrm{~h}$ after E. coli. Gentamicin was given to all groups. TNF and IL-1 were measured by ELISA $( \pm$ SEM).

$* p<0.05$, comparing microencapsulated value with corresponding solution value of TNF or IL- 1 . 


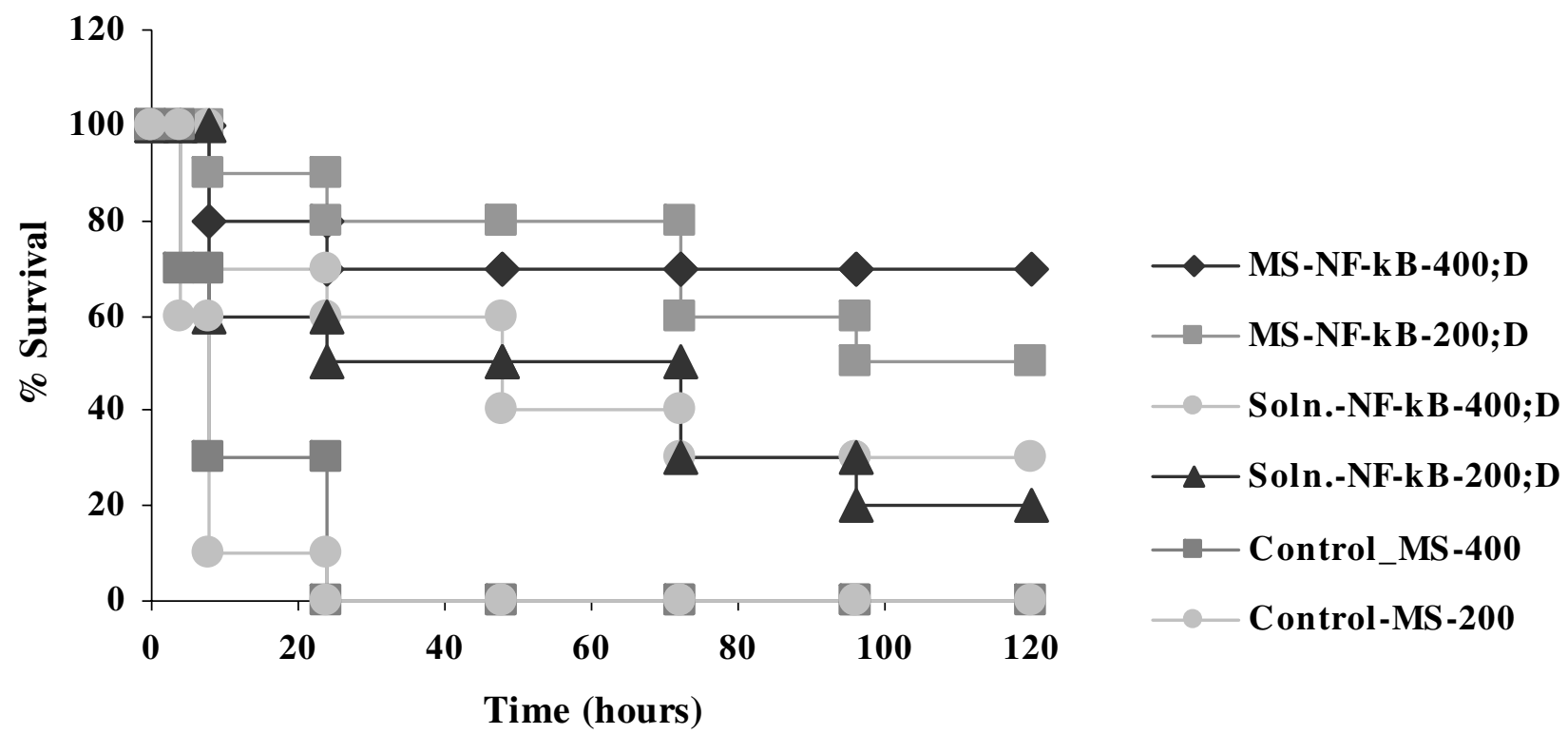

FIG. 4. Kaplan-Meier survival curve with groups identical to those in Figure 3. Treatment with antisense to NF- $\kappa$ B was delayed (D) $4 \mathrm{~h}$ after induction of peritonitis. $p \leq 0.05$ in comparing each solution group with the corresponding dose of microencapsulated (MS) antisense to NF- $\kappa \mathrm{B}$.

of endotoxic shock and peritonitis treated with microencapsulated antisense oligomer. Microencapsulated antisense to $\mathrm{NF}-\kappa \mathrm{B}$ produced significantly greater inhibition of TNF than antisense to TNF when compared directly to each other in the whole blood model.

These results confirm and extend our previous observations using microencapsulated antisense oligomers to TNF in the models of endotoxic shock and bacterial peritonitis. ${ }^{(25)}$ The discovery of NF- $\kappa \mathrm{B}$ as the nuclear transcription factor responsible for initiating proinflammatory cytokine synthesis has led to the search for activation of NF- $\kappa \mathrm{B}$ in various inflammatory states, such as sepsis, rheumatoid arthritis, inflammatory bowel disease, glomerulonephritis, and other conditions. ${ }^{(8-19)}$ Local administration of antisense to animals with experimental colitis decreased inflammation. ${ }^{(14,15)}$

Several human studies have found correlations between $\mathrm{NF}-\kappa \mathrm{B}$ activation and patient survival in septic states. ${ }^{(8-10)}$ However, there have been no published reports systematically documenting TNF inhibition by antisense to NF- $\kappa \mathrm{B}$ in either in vitro or in vivo models. To our knowledge, there have been only two published studies using antisense to NF- $\kappa \mathrm{B}$ in the treatment of experimental sepsis. ${ }^{(34,35)}$ Neither study demonstrated favorable results to treatment in either Staphlococcus aureus or Salmonella typhimurium sepsis. Treatment of mice with $800 \mu \mathrm{g}$ antisense to NF- $\kappa \mathrm{B}$ produced improvement in survival of mice only when given $24 \mathrm{~h}$ before the infectious challenge with S. typhimurium. ${ }^{(34)}$ Pretreatment appeared to be necessary to allow time for intracellular penetration of the oligomer to interact with cytoplasmic NF- $\kappa$ B. In our study, microencapsulated antisense oligomers to NF- $\kappa \mathrm{B}$ produced $70 \%$ survival in the endotoxic shock model and $80 \%$ survival in peritonitis when treatment was initiated simultaneously with the infection. More importantly, $70 \%$ survival was seen when treatment was initiated $4 \mathrm{~h}$ after infection, at which time TNF release is at its peak in this model. Improvement in survival of animals indicates that intervention can be given successfully after induction of the infection when maximal cytokine release has occurred. This is crucial in the treatment of human infection, as infections are always recognized clinically after a variable delay. Additionally, success in this model is important, as localized experimental infections have not been successfully treated using both antibiotics and i.v. TNF neutralizing antibodies. ${ }^{(36)}$

Failure of improving survival in septic shock using neutralizing antibodies to TNF has also been true for numerous human trials. ${ }^{(37)}$ In our studies, survival was also observed in this model using antisense oligomers in solution given i.v., but it was significantly less than observed with microencapsulated oligomer. We have observed similar results in previous studies using neutralizing antibodies to TNF and IL-1, CNI-1493, and antisense to TNF. ${ }^{(25,27-30)}$ The improved effect in this model likely results from redistribution of macrophages that have phagocytized drug-containing microspheres to the area of infection. ${ }^{(30)}$ Chemotactic factors cause rapid migration of macrophages to areas of inflammation. ${ }^{(38,39)}$ Intracellular release of cytokine-inhibiting compounds also is much more efficient in cytokine inhibition, as seen in the whole blood model, where equivalent amounts of drug in solution are compared with the microencapsulated form. All the microencapsulated cytokineinhibiting drugs evaluated to date have produced significantly greater cytokine inhibition than comparable doses of the drug in solution.

In conclusion, the TNF inhibition and animal survival produced by antisense to NF- $\kappa \mathrm{B}$ in both the endotoxic shock model and bacterial peritonitis is more potent than that observed with an equivalent dose of antisense of TNF antisense oligomers. In addition, the antisense to NF- $\kappa \mathrm{B}$ also inhibits IL- 1 and IL- 6 , albeit to a lesser degree. Other pro-inflammatory cytokines were not evaluated but may be inhibited as well. The wide scope of 
action by antisense to NF- $\kappa \mathrm{B}$ in initiation of the inflammatory response makes it a potentially ideal agent in the treatment of inflammatory conditions. From these studies, microencapsulation of antisense oligomers to NF- $\kappa \mathrm{B}$ greatly potentiates its therapeutic effects in experimental sepsis.

\section{ACKNOWLEDGMENT}

Funding for this work was provided by Dialysis Clinic Inc., Nashville, Tennessee.

\section{REFERENCES}

1. BARNES, P.J., and KARIN, M. (1997). Nuclear factor- $\kappa$ B-a pivotal transcription factor in chronic inflammatory diseases. N. Engl. J. Med. 336, 1066-1071.

2. PAHL, H.L. (1999). Activators and target genes of Rel/Nf- $\kappa$ B transcription factors. Oncogene 18, 6853-6866.

3. HATADA, E.N., KRAPPMANN, D., and SCHEIDEREIT, C. (2000). NF- $\kappa$ B and the innate immune response. Curr. Opin. Immunol. 12, 52-58.

4. CHEN, F., CASTRAnOVA, V., SHI, X., and DEMERS, L.M. (1999). New insights into the role of nuclear factor NF- $\kappa$ B, a ubiquitous transcription factor in the initiation of diseases. Clin. Chem. 45, 7-17.

5. MERCURIO, F., and MANNING, A.M. (1999). Multiple signals converging on NF- $\kappa$ B. Curr. Opin. Cell Biol. 11, 226-232.

6. HARTMANN-PETERSEN, R., SEEGER, M., and GORDON, C. (2003) Transferring substrates to the $26 \mathrm{~S}$ proteasome. Trends Biochem. Sci. 28, 26-30.

7. BEN-NERIAH, Y. (2002). Regulatory functions of ubiquitination in the immune system. Nat. Immunol. 3, 20-26.

8. BOHRER, H.F., ZIMMERMAN, T., ZHANG, Y., JLLMER, T., MANNEL, D., BOTTIGER, B.W., STERN, D.M., WALDHERR, R., SAEGER, H., ZIEGLER, R., BIERHAUS, A., MARTIN, E., and NAWROTH, P.P. (1997). Role of NF- $\kappa$ B in the mortality of sepsis. J. Clin. Invest. 100, 972-985.

9. PETERSON, R.L., GALLEY, H.F., DHILLON, J.K., and WEBSTER, N.R. (2000). Increased nuclear factor $\kappa$ B activation in critically ill patients who die. Crit. Care Med. 28, 1047-1051.

10. ARNALICH, F., GARCIA-PALOMERO, E., LOPEZ, J., JIMENEZ, M., MADERO, R., RENART, J., VAZQUEZ, J.J., and MONTIEL, C. (2000). Predictive value of nuclear factor $\kappa \mathrm{B}$ activity and plasma cytokine levels in patients with sepsis. Infect. Immun. 68, 1942-1945.

11. NEURATH, M.F., and PETTERSON, S. (1997). Predominant role of NF- $\kappa$ B in the pathogenesis of chronic intestinal inflammation. Immunobiology 198, 91-98.

12. ROGLER, G., BRAND, K., VOGL, D., PAGE, S., HOFMEISTER, R., ANDUS, T., KNUECHEL, R., BAEUERLE, P.A., SCHOLMERICH, J., and GROSS, V. (1998). Nuclear factor $\kappa \mathrm{B}$ is activated in macrophages and epithelial cells of inflamed intestinal mucosa. Gastroenterology 115, 357-369.

13. SCHMID, R.M., and ADLER, G. (2000). NF- $\kappa$ B/Rel/I $\kappa$ B: implications in gastrointestinal diseases. Gastroenterology 118, 12081228.

14. NEURATH, M.F., PETTERSON, S., BUSCHENFELDE, K.H.M., and TROBER, W. (1996). Local administration of antisense phosphorothioate oligonucleotides to the p65 subunit of NF- $\kappa$ B abrogates established experimental colitis in mice. Nat. Med. 2, 998-1004.

15. MURANO, M., MAEMURA, K., HIRATA, I., TOSHINA, T., NISHIKAWA, T., HAMAMOTO, S., and SASAKI, S. (2000).
Therapeutic effect of intercolonically administered nuclear factor $\kappa \mathrm{B}$ (p65) antisense oligonucleotide on mouse dextran sulphate sodium (DSS) -induced colitis. Clin. Exp. Immunol. 120, $51-58$.

16. TOMITA, T., TAKANO, H., TOMIKTA, N., MORISHITA, R., KANEKO, K., SHI, K., TAKAHI, K., NAKASE, T., KANEDA, Y., YOSHIKAWA, H., and OCHI, T. (2000). Transcription factor decoy for NF- $\kappa$ B inhibits cytokine and adhesion molecule expressions in synovial cells derived from rheumatoid arthritis. Rheumatology 29, 749-757.

17. YAMASAKI, S., KAWAKAMI, A., NAKASHIMA, T., NAKAMURA, K., KAMACHI, M., HONDA, S., HIRAI, Y., HIDA, A., IDA, H., MIGITA, K., KAWABE, Y., KOJI, T., FURUICHI, I., AOYAGI, T., and EGUCHI, K. (2001). Importance of NF-kB in rheumatoid synovial tissues: in situ NF- $\kappa \mathrm{B}$ expression and in vitro study using cultured synovial cells. Ann. Rheum. Dis. 60, 678-684.

18. MIAGKOV, A.V., KOVALENKO, D.V., BROWN, C.E., DIDSBURY, J.R., COGSWELL, J.P., STIMPSON, S.A., BALDWIN, A.S., and MARAKOV, S.S. (1998). NF- $\kappa$ B activation provides the potential link between inflammation and hyperplasia in the arthritic joint. Proc. Natl. Acad. Sci. USA 95, 13859-13864.

19. SAKURAI, H., HISADA, Y., UENO, M., SUGIURA, M., KAWASHIMA, K., and SUGITA, T. (1996). Activation of transcription factor NF- $\kappa \mathrm{B}$ in experimental glomerulonephritis in rats. Biochim. Biophys. Acta 1316, 132-138.

20. CHRISTMAN, J.W., LANCASTER, L.H., and BLACKWELL, T.S. (1998). Nuclear factor $\kappa \mathrm{B}$ : a pivotal role in the systemic inflammatory response syndrome and new target for therapy. Intens. Care Med. 24, 1131-1138.

21. BALDWIN, A.S. (2001). The transcription factor NF- $\kappa$ B and human disease. J. Clin. Invest. 107, 3-6.

22. TAK, P.P., and FIRESTEIN, G.S. (2001). NF- $\kappa$ B: a key role in inflammatory diseases. J. Clin. Invest. 107, 7-11.

23. ZHANG, G., and GHOSH, S. (2001). Toll-like receptor-mediated NF- $\kappa$ B activation: a phylogenetically conserved paradigm in innate immunity. J. Clin. Invest. 107, 13-19.

24. GHOSH, C., and IVERSEN, P.L. (2001). Intracellular delivery for antisense phosphorodiamitate morpholino oligomers. Antisense Nucleic Acid Drug Dev. 10, 263-274.

25. OETTINGER, C.W., and D'SOUZA, M.J. (2003). Microencapsulation of TNF oligomers: a new approach to pro-inflammatory cytokine inhibition. J. Interferon Cytokine Res. 23, 533-543.

26. OLIVER, J.C., BLAND, L.A., and OETTINGER C.W. (1993). Cytokine kinetics in an in-vitro whole blood model following an endotoxin challenge. Lymphokine Cytokine Res. 12, 115-120.

27. D'SOUZA, M.J., OETTINGER, C.W., and MILTON, G.V. (1999). Evaluation of microspheres containing cytokine neutralizing antibodies in endotoxemia. Drug Dev. Indust. Pharm. 25, 727-734.

28. D’SOUZA, M .J., OETTINGER, C.W., MILTON, G.V., and TRACEY, K.J. (1999). Prevention of lethality and suppression of proinflammatory cytokines in experimental septic shock by microencapsulated CNI-1493. J. Interferon Cytokine Res. 19, $1125-1133$.

29. D'SOUZA, M.J., OETTINGER, C.W., and MILTON, G.V. (2000). Microspheres containing neutralizing antibodies to tumor necrosis factor-á and interleukin- $1 \beta$ protect rats from Staphlococcus aureusinduced peritonitis. J. Interferon Cytokine Res. 20, 907-913.

30. OETTINGER, C.W., D'SOUZA, M.J., and MILTON, G.V. (1999). Targeting macrophages with microspheres containing cytokineneutralizing antibodies prevents lethality in gram-negative peritonitis. J. Interferon Cytokine Res. 19, 33-40.

31. D'SOUZA, M.J., OETTINGER, C.W., SHAH, A., TIPPING, P.G., XIAO, R.H., and MILTON, G.V. (1999). Macrophage depletion by albumin microencapsulated clodronate: attenuation of cytokine release in macrophage-dependent glomerulonephritis. Drug Dev. Indust. Pharm. 25, 591-596. 
32. POURFARZIB, R., GAJJAR, D., RIADI, I., and D'SOUZA, M.J. (1993). Enzyme-linked immunosorbent assay for detection of human tumor necrosis factor alpha. Pharm. Res. 10, S-77.

33. POURFARZIB, R., GAJJAR, D., RIADI, I., and D'SOUZA, M.J. (1993). Enzyme-linked immunosorbent assay for detection of human interleukin 1 beta. Pharm. Res. 10, S-77.

34. SCHLAAK, J.F., BARREIROS, A.P., PETTERSON, S., SCHIRMACHER, P., MEYER ZUM BUSCHENFELDE, K.-H., and NEURATH, M.F. (2001). Antisense phosphorothioate oligonucleotides to the p65 subunit of NF- $\kappa$ B abrogate fulminant septic shock induced by S. typhimurium in mice. Scand. J. Immunol. 54, 396-403.

35. GJERTSSON, I., HULTGREN, O.H., COLLINS, L.V., PETTERSON, S., and TARKOWSKI, A. (2001). Impact of transcription factors AP-1 and NF- $\kappa$ B on the outcome of experimental Staphlococcus aureus arthritis and sepsis. Microbes Infect. 3, 527-534.

36. BAGBY, G., KIRBY, J., PLESSALS, J., WILSON, L.A., THOMPSON, J.J., and NELSON, S. (1991). Divergent efficacy of antibody to tumor necrosis factor-á in intravascular and peritonitis models of sepsis. J. Infect. Dis. 163, 83-88.

37. ZANOTTI, S., KUMAR, A., and KUMAR, A. (2002). Cytokine modulation in sepsis and septic shock. Expert Opin. Invest. Drugs 11, 1061-1075.
38. ISSEKUTZ, A.C., and ISSEKUTZ, T.B. (1993). Quantitation and kinetics of blood monocyte migration to inflammatory reactions and IL $1 \alpha$, tumor necrosis factor $\alpha$, and IFN- $\gamma$. J. Immunol. 151, 2105-2115.

39. BOSSINK, A., PAEMAN, L., JANSEN, P.M., HACK, C.E., THIJS, L.G., and VAN DAMME, J. (1995). Plasma levels of the chemokines monocytic chemotactic proteins- 1 and-2 are elevated in human sepsis. Blood 86, 3841-3847.

Address reprint requests to:

Dr. Carl W. Oettinger 820 West Peachtree Street Suite 102 Atlanta, GA 30308

Tel: (404) 888-4540

Fax: (404) 888-0182

E-mail: coettinger@aol.com

Received 12 March 2004/Accepted 10 January 2005 